\title{
Young Voters after the 2008 Election: A Disappearing Act?
}

\author{
Priscilla Southwell ${ }^{1}$ \\ ${ }^{1}$ Department of Political Science, University of Oregon, Eugene, OR, USA \\ Correspondence: Priscilla Southwell, Department of Political Science, University of Oregon, Eugene, OR, USA. \\ E-mail: psouth@uoregon.edu
}

Received: March 17, 2016 Accepted: June 11, 2016 Online Published: August 30, 2016

doi:10.5539/jpl.v9n7p80

URL: http://dx.doi.org/10.5539/jpl.v9n7p80

\begin{abstract}
This study examines the decline in voter turnout among young voters between the 2008 and 2012 elections. Our findings suggest that those young voters who dropped out of the electorate in 2012 were more likely to express feelings of alienation, as measured by the American National Election Studies indices of trust and efficacy. Such "dropout" voters were also more likely to have voted for Barack Obama in the 2008 election. These findings are crucial, as the level of alienation in the 2016 election appears to be even higher, and may influence the outcome of the election.
\end{abstract}

Keywords: turnout, alienation, trust, efficacy

\section{Introduction}

Previous analysis of the 2008 presidential election suggests that the mobilization efforts of the Obama campaign led to a dramatic increase in voter registration among young people. These efforts led to a narrowing of the turnout gap between young voters and the rest of the electorate in this election (Keeter et al., 2008). However, this mobilization of young voters was not sustained in the subsequent elections, as shown in Tables 1 and 2 below. Although voter turnout dropped slightly among all age cohorts, the decline from $44.3 \%$ to $38 \%$ among 18-to-24 year-olds was much sharper.

Table 1. Voter turnout and age presidential elections, 2004-2014

\begin{tabular}{llll}
\hline Age & $\mathbf{2 0 0 4}$ & $\mathbf{2 0 0 8}$ & $\mathbf{2 0 1 4}$ \\
\hline 18 to 24 years & 41.9 & 44.3 & 38.0 \\
25 to 44 years & 52.2 & 51.9 & 49.5 \\
45 to 64 years & 66.6 & 65.0 & 63.4 \\
65 years and over & 68.9 & 68.1 & 69.7 \\
\hline
\end{tabular}

Source: U.S. Census Bureau, 2016b

Table 2. Voter turnout and age congressional elections, 2006-2012

\begin{tabular}{lccc}
\hline Age & $\mathbf{2 0 0 6}$ & $\mathbf{2 0 1 0}$ & $\mathbf{2 0 1 2}$ \\
\hline 18 to 24 years & 19.9 & 19.6 & 15.9 \\
25 to 44 years & 34.4 & 32.2 & 28.3 \\
45 to 64 years & 54.3 & 51.1 & 46.0 \\
65 years and over & 60.5 & 58.9 & 57.5 \\
\hline
\end{tabular}

Source: U.S. Census Bureau, 2016a

The signs of this "disappearing act" came soon after the 2008 election. Turnout among young people in the 2009 New Jersey and Virginia gubernatorial elections was $19 \%$ and $17 \%$ respectively. Similarly, in the 2010 special U.S. Senate election in Massachusetts, turnout among young voters was only 15\% (CIRCLE, 2010). So what 
happened to the enthusiasm of young voters between Inauguration Day 2009 and Election Day 2010? Was it the stubbornly high employment figures? The continuation of the Wall Street bailout? The resumption of military trials for the Guantanamo detainees? The compromises on the health care bill? The BP oil spill? Did the Democratic Party ignore young voters? Anecdotal indicators suggest that young voters (and nonvoters) were quite concerned about the economy (CIRCLE, 2010) and were disillusioned about the progress of the Obama administration in achieving its stated goals. In the year following his inauguration, Obama's approval ratings fell from $73 \%$ to $57 \%$ among young people (Cox, 2010). This study examines voting data from the 2012 election in an attempt to investigate this dropout phenomenon among younger voters.

\section{Previous Research}

Even before the adoption of the $26^{\text {nd }}$ Amendment in 1971, which lowered the voting age to 18 , younger voters have traditionally voted less often than the rest of the citizenry. This lower-than-average turnout of young people has been attributed to numerous factors, such as a "life-cycle" effect, a "generational" effect, or a "period" effect. The life cycle effect (Highton and Wolfinger 2001; Verba and Nie 1972; Verba and Nie. 1998; Wolfinger and Rosenstone, 1980) emphasizes that young people are often preoccupied with their desire for educational achievement or initial employment, as well as being more transitory. Young people initially lack the political awareness and societal commitment, yet these attributes usually emerge as they grow older and form more stable ties to their community, state, and nation. Evidence has also emerged of a generation or cohort effect, where the process of political socialization can affect a particular age cohort, such that their level of political engagement and involvement differs from their parents. Closely related is a "period" effect, which emphasizes the impact of a series of particular political events or developments, such as Vietnam or Watergate, which shape or alter the political inclinations of young persons who are at a crucial, impressionable stage in their political development (Phelps 2004).

In the last decade, it appears that the political awareness and engagement of young people has grown, after a decisive slump in the 1990s, and this ameliorating trend has resulted in an increase in voter turnout among young people. Most analyses have concluded that this increase was due to a growing attachment among young people to the Democratic party, culminating in their overwhelming support for the candidacy of Barack Obama in 2008 (Keeter et al. 2008). The increase in turnout from 2004 to 2008 for young people was the only statistical significant increase between these two elections (U.S. Census Bureau, 2010).

\section{Political Alienation as an Explanation}

What explains this young dropout voter? Most "life style" explanations assume that once a person enters the electorate, he or she is apt to become a habitual voter (Plutzer, 2002). Preliminary accounts suggest that alienated attitudes contributed to this lower turnout among young people in 2010 (Page, 2010). As Phelps (2004, p. 245) suggests: " A generational shift may represent the disillusionment with a political process that is dated and unresponsive to the needs of modern citizens who are coming to conceptualize politics within a broader framework of social and political issues, and who are unable to comprehend a system designed to solve the problems of a different era."

Previous research on the linkage between alienation and participation is complex, as the various dimensions of alienation have a differing impact on turnout (Southwell, 2008). Often "cynicism," also referred to as distrust, will lead an individual to vote, in order to "throw the rascals out," (Citrin, 1974), but a clearly identifiable alternative party or candidate has to be available (Southwell and Everest, 1998). CIRCLE's (2010c) analysis suggests that the message and candidates of the Tea Party did not resonate with young people in 2010.

Another dimension of alienation, "inefficacy," has also been linked to nonvoting (Clarke and Acock 1989; Finifter 1970; Niemi 1978; Southwell 2008). If an individual feels that he or she cannot have an impact on the political system, abstention may result. This reaction is especially predictable when one's political hopes and aspirations were previously high, as with young people in 2008 - a "rising expectations" phenomenon. As such, many disillusioned youth may have just chosen to sit this one out.

\section{Methodology}

The multivariate analysis, presented in Table 3 below, examines data from the 2012 American National Election Series (Prysby and Scavo, 2014). We created a dependent variable to identify "dropout voters;" those who voted in 2008 but did not vote in the 2012 election. We then used binary logit analysis to control for the standard demographic and attitudinal variables that are typically used to predict voter turnout. The results are shown in Model A below. As expected, older, wealthier individuals were more likely to vote, as were those with strong party attachments. Feeling political inefficacious was linked to nonvoting, but the variable for cynicism was 
insignificant. The education, gender, and race variables were also insignificant.

In Model B, we add in two interactive variables that control for young persons who also show signs of inefficacy and political distrust. This model provides a partial explanation for this phenomenon - young people who were more alienated from the political system were more like to stay home in the 2012 election.

Table 3. Binary logistic analysis of dropout voting 2008-2012

\begin{tabular}{|c|c|c|c|c|c|c|}
\hline & 2012 & & & 2012 & & \\
\hline & Model A & & & Model B & & \\
\hline Variable & Coeff. & & (SE) & Coeff. & & (SE) \\
\hline Education & -.017 & & $(.058)$ & -.010 & & $(.055)$ \\
\hline Age & $-.177 * * *$ & & $(.036)$ & & - & \\
\hline Nonwhite race & .059 & & $(.081)$ & .083 & & $(.058)$ \\
\hline Male & .019 & & $(.119)$ & .076 & & $(.116)$ \\
\hline Strength of Partisanship & $-.160 * * *$ & & $(.071)$ & $-.204 * * *$ & & $(.068)$ \\
\hline Income & $-.093 * *$ & & $(.039)$ & $.182 * * *$ & & $(.026)$ \\
\hline Feeling of Powerlessness & $.161 * * *$ & & $(.047)$ & & - & \\
\hline Feeling of Cynicism & -.019 & & $(.078)$ & & - & \\
\hline Under 30 and Powerless & & - & & $.500 * *$ & & $(.189)$ \\
\hline Under 30 and Cynical & & - & & .178 & & $(.197)$ \\
\hline Constant & -1.213 & & $(.359)$ & -2.359 & & $(.304)$ \\
\hline Cox \& Snell R Square & .032 & & & .007 & & \\
\hline Nagelkerke R Square & .011 & & & .021 & & \\
\hline-2 Log likelihood & 2308.573 & & & 2449.484 & & \\
\hline
\end{tabular}

$* * * \mathrm{p}<.001 ; * * \mathrm{p}<.01 ; * \mathrm{p}<.05$

$\mathrm{N}=5507$

Source: Prysby, Charles and Carmine Scavo. 2014. American Political Science Association, and Inter-university Consortium for Political and Social Research.

\section{Consequences of Dropout Voters}

Did the drop in turnout among young voters have a consequence for the two major parties? As indicated in the Table 4 below, a strong majority of these dropout voters had voted for Obama in the 2008 election, but did not return to vote for him, or anyone else, in the 2012 election. Obviously Barack Obama was re-elected for a second term, but this shift in the electorate may help to explain the Democratic loss of both the U.S. and the Senate during these years.

Table 4. 2008 presidential vote preference of dropout voters

\begin{tabular}{ccccc}
\hline \multicolumn{5}{c}{ 2008 Presidential Vote } \\
\hline & Obama & McCain & Other & Did not Vote \\
\hline $\begin{array}{c}\text { Voted in } 2012 \\
\text { (5495) }\end{array}$ & $45.3 \%$ & $29.1 \%$ & $1.8 \%$ & $23.8 \%$ \\
$\begin{array}{c}\text { Did not vote in } 2012 \\
\text { (332) }\end{array}$ & $64.2 \%$ & $31.0 \%$ & $4.8 \%$ & $0.0 \%$ \\
\hline
\end{tabular}

Source: Prysby, Charles and Carmine Scavo. 2014. American Political Science Association, and Inter-university Consortium for Political and Social Research. 


\section{Possible Remedies}

More instrumental methods to entice young people back to the polls include making the polls more accessible by early voting (Gronke, 2007; Nichols, 2010), more liberalized absentee voting provisions (CIRCLE, 2010c), electoral day registration (Knack and White 2002), and all-mail voting, as occurs in Oregon and Washington (Southwell, 2009). CIRCLE has shown that states that allowed for Election Day registration averaged 59\% turnout among 18-19 year olds, as compared to 50\% in other states (Kawashima-Ginsberg et al., 2009). Oregon has also become the first state to automatically register citizens if they have had any contact with the state's Division of Motor Vehicles.

Given how pivotal the youth vote was in 2008 , it is unlikely that either party will ignore younger people in the path to both the nomination and the general election in 2016. There is a growing body of support for the effectiveness of personal contact in mobilization (Gerber and Green, 2000). At the time of this writing, the exit polls at primaries and caucuses indicated the Democratic candidate Bernie Sanders appears to have been quite effective in attracting the attention and devotion of young voters. However, if he fails to get his party's nomination, will these young people continue to vote, and engage in a second disappearing act?

\section{References}

CIRCLE. (2010a). Reweighted Exit Poll Suggests Youth Turnout May Have Reached 22.8\%. Retrieved from http://www.civicyouth.org/reweighted-exit-poll-data-suggest-youth- turnout-may-have-reached-22-8/

CIRCLE. (2010b). Young voters in the 2010 Election. Retrieved from http://www.civicyouth.org/wp-content/uploads/2010/11/2010-Exit-Poll-FS-Nov-17-Update.pdf

CIRCLE. (2010c). Youth voting. Retrieved from http://www.civicyouth.org/quick-facts/youth-voting/

Citrin, J. (1974). Comment: The political relevance of trust in Government. American Political Science Review, 68, 973-988. http://dx.doi.org/10.2307/1959141

Clarke, H., \& Acock, A. (1989). National elections and political attitudes: The case of political efficacy. British Journal of Political Science, 19, 551-562. http://dx.doi.org/10.1017/S0007123400005639

Cox, W. (2012). The youth vote and the war of 2012. American Chronicle, (9).

Erikson, R. S. (1981). Why do people vote? Because they are registered. American Politics Quarterly, 9, 259276. http://dx.doi.org/10.1177/1532673X8100900301

File, T. (2013). Young-Adult voting: An analysis of presidential elections, 1964-2012. Current Population Survey Reports, P20-572. U.S. Census Bureau, Washington, DC.

Finifter, A. (1970). Dimensions of political alienation. American Political Science Review, 65, 329-341. http://dx.doi.org/10.2307/1953840

Gerber, A. S., \& Green, D. P. (2000). The effects of canvassing, direct mail, and telephone contact on voter turnout: A field experiment. American Political Science Review, 94, 653-663. http://dx.doi.org/10.2307/2585837

Gronke, P., Galanes-Rosenbaum, E., \& Miller, P. (2007). Early voting and turnout. PS: Political Science and Politics, 40, 639-645. http://dx.doi.org/10.1017/s1049096507071028

Highton, B., \& Wolfinger, R. E. (2001). The first seven years of the political life cycle. American Journal of Political Science, 45, 202-209. http://dx.doi.org/10.2307/2669367

Kawashima-Ginsberg, K., Nover, A., \& Kirby, E. H. (2009). State election law reform and youth voter turnout. CIRCLE Fact Sheet, July.

Keeter, S., Horowitz, J., \& Tyson, A. (2008). Young voters in the 2008 election. Pew Research Center for the Press \& the Press, November 12.

Knack, S., \& White, J. (2000). Election-Day registration and turnout inequality. Political Behavior, 22, 29-44. http://dx.doi.org/10.1023/A:1006638400784

Nichols, J. (2010). Young voter turnout fell 60\% from 2008 to 2010: Dems won't win in 2012 if the trend continues. The Nation, November 16.

Nickerson, D. W. (2006). Hunting the elusive young voter. Journal of Political Marketing, 5, 47-69. http://dx.doi.org/10.1300/J199v05n03_03

Niemi, R. G., Craig, S. C., \& Mattei, F. (1991). Measuring internal political efficacy in the 1988 national election 
study. American Political Science Review, 85, 1407-1441. http://dx.doi.org/10.2307/1963953

Page, S. (2010). Obama coalitions frays amidst voter angst, recession. USA Today, November 3.

Phelps, E. (2004). Young citizens and changing electoral turnout. The Political Quarterly, 75, 238-248. http://dx.doi.org/10.1111/j.1467-923X.2004.00608.x

Plutzer, E. (2002). Becoming a habitual voter: Inertia, resources, and growth in young adulthood. American Journal of Political Science, 96, 41-56. http://dx.doi.org/10.1017/S0003055402004227

Prysby, C., \& Scavo, C. (2014). American Political Science Association, and Inter-university Consortium for Political and Social Research. SETUPS: Voting Behavior: The 2012 Election. ICPSR34808-v2. Ann Arbor, MI: Inter-university Consortium for Political and Social Research.

Southwell, P. L. (2008). The effect of political alienation on voter turnout: 1964-2000. Journal of Political and Military Sociology, 36, 131-146.

Southwell, P. L. (2009). Analysis of the turnout effects of vote by mail elections, 1980-2007. The Social Science Journal, 46, 211-217. http://dx.doi.org/10.1016/j.soscij.2008.12.010

Southwell, P. L., \& Everest, M. (1998). The electoral consequences of alienation: nonvoting and third party voting in the 1992 presidential race. The Social Science Journal, 35, 43-52. http://dx.doi.org/10.1016/S0362-3319(98)90058-1

U.S. Census Bureau. (2009). Voter turnout increases by 5 million in 2008 presidential election. U.S. Census Bureau, July 20.

U.S. Census Bureau. (2016a). Table A-7. Reported voting rates in congressional election years by selected characteristics: November 1966 to 2014. Retrieved from https://www.census.gov/hhes/www/socdemo/voting/publications/historical/index.html

U.S. Census Bureau. (2016b). Table A-9. Reported voting rates in presidential election years, by selected characteristics: November 1964 to 2012. Retrieved from https://www.census.gov/hhes/www/socdemo/voting/publications/historical/index.html

Verba, S., \& Nie, N. (1972). Participation in America. New York: Harper \& Row.

Verba, S., Nie, N., \& Kim, J. (1978). Participation and Political Equality. Chicago: University of Chicago Press.

Wolfinger, R. E., \& Rosenstone, S. J. (1980). Who Votes? New Haven, CT: Yale.

\section{Copyrights}

Copyright for this article is retained by the author(s), with first publication rights granted to the journal.

This is an open-access article distributed under the terms and conditions of the Creative Commons Attribution license (http://creativecommons.org/licenses/by/4.0/). 